\title{
The Two Tales of Forced Labour: Katorga and Reformed Prison in Imperial Russia (1879-1905)
}

DOI: http://dx.doi.org/10.1590/2236-463320161406

Zhanna Popova

International Institute of Social History, Amsterdam, Netherlands zhannapop@gmail.com

\begin{abstract}
This article explores the advance of the prison reform in the Russian Empire. It examines the governmental department that was the driver of this reform, the Main Prison Administration, and focuses on its policy in the domain of the forced labour of prisoners. Two types of forced labour are of particular interest here. One is the traditional hard penal labour, or katorga, and the other is the obligatory labour for the prisoners serving shorter terms. I outline here how this second type of labour came to play the decisive role in the discourse on punishment in the late imperial period, what kind of conceptions supported it, and how it was implemented throughout the empire.
\end{abstract}

Keywords: penal reform, prisons, convict labour, global history

\section{Introduction}

The penal reform has already been identified in the literature as a global phenomenon ${ }^{1}$. However, over long time the research of penal regimes has been focusing on very specific geographical contexts, generally Western or Northern European ones ${ }^{2}$, and the global character of the prison reform had largely been

\footnotetext{
${ }^{1}$ DIKÖTTER, Frank. The Promise of Repentance: Prison Reform in Modern China. The British Journal of Criminology, vol. 42. no.2, spring 2002, p. 240.

${ }^{2}$ Some examples of such research are FOUCAULT, Michel. Surveiller et punir. Paris: Gallimard, 1975; IGNATIEFF, Michael. A Just Measure of Pain: Penitentiaries in the Industrial Revolution, 1780-1850.
} 
neglected in the scholarship until the beginning of the 2000s. In his programmatic article on prisons in modern China, Frank Dikötter suggested that the unfolding of this reform was not a mere dissemination of practices and knowledge from the "West" to other countries, but a creative process of circulation, inculturation and mutual influence ${ }^{3}$. In this article, I seek to contribute to the scholarship of the global penal reform by examining the Russian case4.

The history of Imperial punishments has largely been overshadowed by the history of the far bigger institutions that came later: the Soviet labour camps. However, these later developments cannot be fully understood without the study of the early attempts to modernize the penal system. Some of the ideas and practices first articulated and probed by the Imperial prison officials were later appropriated by the Gulag officials. Daniel Beer examined a similar seemingly improbable inheritance by focusing on the human sciences (namely, criminology, psychology and psychiatry) in Russia at the turn of the centuries: as he argues, "the Bolsheviks' own conception of societal renovation (and the nature of the forces impeding it), was heavily indebted to visions of reform and progress articulated by liberal elites in the fin-de-siècle" ${ }^{\text {. }}$. Here I do not examine the questions of continuity in detail, but analyze the main traits of development of the Imperial penal system in the last decades of the nineteenth century.

Some of these transformations have already been approached in the literature ${ }^{6}$. Scholars studied the reforms, namely the reform of corporal punishment of $1863^{7}$ and the prison reform of 1879 , through the analysis of the discussions among the highestranking officials. The book by Bruce Adams, for instance, is a painstaking

London: Macmillan, 1978; SPIERENBURG, Pieter. The Prison Experience: Disciplinary Institutions and their Inmates in Early Modern Europe. New Brunswick, London: Rutgers University Press, 1991.

${ }^{3}$ DIKÖTTER. Op. Cit., p. 240-241.

${ }^{4}$ The International Prison Congresses of the second half of the nineteenth century provide another case for the study of the global circulation of the penological knowledge. It is but one of the possible approaches; in the present work I seek to examine how information on prisons was collected and used on the country level, in order to be able to draw comparisons in the future research.

${ }^{5}$ BEER, Daniel. Renovating Russia: the Human Sciences and the Fate of Liberal Modernity, 1880-1930. Ithaca: Cornell University Press, 2008, p. 206.

${ }^{6}$ SCHRADER, Abby M. Languages of the Lash: Corporal Punishment and Identity in Imperial Russia. Dekalb, Illinois: Northern Illinois University Press, 2002; and ADAMS, Bruce F. The Politics of Punishment: Prison Reform in Russia, 1863-1917. DeKalb, Illinois: Northern Illinois University Press, 1996.

${ }^{7}$ Abby Schrader connected the penal practices to the wider political and social context of the Russian Empire: she explored how the punitive practices were also functional as the instruments of colonization. 
reconstruction of the tensions between the Ministry of Interior and the Ministry of Justice surrounding the establishment of the centralized penal system. Such research provides a detailed overview of the decisions that shaped the legal form of the penal system, and it constitutes the base which allows me to approach the administrators of lower levels and the experts who produced knowledge about prisons in the Russian Empire. Decisions of ministers were crucial, but they were generally based upon longrunning work of the officials and administrators of multiple departments, commissions, and subdivisions. This work was much less visible, but pivotal for the shape of the reform. Hence the importance of adopting a perspective that would not be limited to the study of the final legal decisions and the political rivalry between the M inistries.

In this article I'm going to approach the reform through a study of the main administrative innovation it produced: the Main Prison Administration (Glavnoe Tiuremnoe Upravlenie, GTU). Three parts seek to explain how the reform took shape and what long-running impact it had, with a particular focus on the developments in the domain of the forced labour of convicts. First, I will discuss punishments before the reform and outline the legislative and administrative actions that constituted the reform. Second, I will propose a close- up look at one of the heads of the reform and the longest-running head of the GTU (1879-1895), Mikhail Galkin-Vraskoi'. Studying his trajectory will allow to understand the intricate mechanics of the preparation of the reform: as he was one of the drivers behind it, tracing his actions sometimes allows pinpointing precise moments of innovation. The third part is dedicated to unveiling the collective work of knowledge production about the Imperial penal system and the convict labour. Switching between these different units of analysis would allow a more balanced view of the changes of the convict labour from 1879 to 1905 .

\section{Landscape of Russian Punishments Before the Reform}

The defeat of the Russian Empire in the Crimean War is considered to be the moment that made the government realize the necessity of profound reforms ${ }^{9}$. The

\footnotetext{
${ }^{8}$ His surname has several possible spellings. Before 1885 , he would sign the documents as "GalkinVraskii", and after that until his death as "Galkin-Vraskoi". As he himself, as well as the contemporary secondary sources, favoured the latter spelling, I follow them in this.

${ }^{9}$ ZAKHAROVA, Larisa. The reign of Alexander II: a watershed? In: LIEVEN, Dominic (org.) Cambridge History of Russia, vol. 2. Cambridge: Cambridge University Press, 2006, p. 593.
} 
most famous and most transformative of them was the abolition of serfdom in 1861, but the financial reform (1863), the reforms of higher (1863) and middle (1871) education, the judicial reform and the reform of local governance (both from 1864) had as well changed the political and social landscape of the Russian Empire. The prison reform is not traditionally considered to be a part of these "Great Reforms" ${ }^{\text {"10: in }}$ the short-term perspective, it was far less transformative than any of the abovementioned. The legislative acts that shaped this reform and defined the direction of development of the penal system in the decades to come were finished only in 1879. This was the law that created the Main Prison Administration, and the project of legal transformation that was used as a foundation for a new Criminal Code that finally would become effective in 1903. However, this reform was in preparation for almost a decade. During the early 1870s, two committees were organized in order to elaborate its early blueprints. Right from the start, the prison reform was a ground of cooperation and rivalry between the Ministry of Interior and the Ministry of Justice. The committee organized by the latter was preoccupied with the legal part of the penal reform; simultaneously, a special committee headed by Count Sollogub created a project for the prison administration improvements. This project suggested the introduction of the solitary confinement ${ }^{11}$, the obligatory convict labour, and religious education for the convicts, as well as the construction of several new, modern prison buildings ${ }^{12}$. During the same time some practical changes have already been made: in an attempt to alleviate the rampant prison overpopulation, seven military buildings were refurbished as civil prisons ${ }^{13}$.

Finally, the special commission of Konstantin Grot, organized in 1877, worked to incorporate the propositions of the previous commissions and map out a plan for "the organization of the prison affairs (tiuremnoe delo) along more rational principles"14. These works resulted in creation of a law entitled "On the main principles to be observed during the reform of the prison affairs and during the revision of the

\footnotetext{
${ }^{10}$ EKLOF, Ben; BUSHNELL, John; ZAKHAROVA, Larisa Georgievna (org.). Russia's Great Reforms, 18551881. Bloomington and Indianapolis: Indiana University Press, 1994.

${ }^{11}$ Some of the suggestions and the introduction of the solitary confinement for all prisoners in particular have never been realized.

${ }^{12}$ Tiuremnoe preobrazovanie, vol. 1. Saint- Petersburg, 1905, p. 6- 7.

${ }^{13}$ Tiuremnoe preobrazovanie, vol. 1. Saint-Petersburg, 1905, p. 5.

${ }^{14}$ Tiuremnoe preobrazovanie, vol. 1. Saint-Petersburg,1905, p. 9.
} 
Criminal Code". It was passed on 19 December 1879, and thus the Main Prison Administration was created.

From the very beginning the officials were not overly optimistic about the depth and the pace of this reform: as it is stated in the overview of the first ten years of the GTU's activity, "the government has resolutely abandoned the idea of realizing this reform instantly and on a full scale"15. The trade- off between the desire of reform and the lack of means (both financial and administrative) to realize it has been achieved through the decision to start the reform with executive measures, namely the organization of the GTU16.

Abolition of serfdom was one of the events that made the officials realize the pressing necessity of a prison reform. It created a new wave of inmates: as serfs, the peasants were subject to the will of their landlord (pomeschik), who could punish them without being accountable to the state. After abolition of serfdom, however, the freed peasants came under the jurisdiction of the state and therefore were supposed to serve the punishment in the state-sponsored prisons. The existing prison system was decentralized and fragmented, many prison buildings were extremely run-down, living conditions of the prisoners were extremely poor, and overpopulation was critical.

Another event that contributed to the crisis of the prison system was the reform of the corporal punishment. Prior to 1863, corporal punishment, along with the exile, was the predominant type of punishment in the Russian Empire. Despite the fact that Empress Elizaveta Petrovna suspended the death penalty for common criminals in 1754, thus legally making katorga ${ }^{17}$ the gravest punishment, the officials admitted later that punishment by knout ${ }^{18}$ constituted a qualified death penalty ${ }^{19}$. Knout was abolished by Nicholas I in 1845, and even more change has been brought by the reform of 1863. This reform did not completely abolish corporal punishment, but its use was significantly curbed. Lash (plet) was abolished as a separate punishment and as a part

\footnotetext{
${ }^{15}$ Obzor desiatiletnei deiiatelnosti Glavnogo tiuremnogo upravleniia, 1879-1889. Saint-Petersburg, 1889, p. 1.

${ }^{16}$ Tiuremnoe preobrazovanie, vol. 1. Saint-Petersburg, 1905, p. 8.

${ }^{17}$ Katorga was a complex punishment combining hard physical labour and exile (and, prior to 1863, corporal punishment). It could be administered for terms from 4 to 25 years, followed by "eternal" exile. I will talk more about it in the final part of the article.

${ }^{18}$ Knout is a type of heavy whip, somewhat similar to scourge; it could have many varieties, some of which had wires and other metal parts.

${ }^{19}$ RGIA (Russian State Historical Archive, Saint- Petersburg), f.1151 op. 15 d. 196, I. 2.
} 
of punishment for those sentenced to katorga and exile, but it was still used as a disciplinary punishment for those who were already serving their katorga and exile terms. In other words, for the wrongdoings that convicts would have committed while serving their term, they could be punished by up to 100 hits of lash. In the same way, birching was abolished as a part of punishment for those sentenced to prison, but it was still used against the male exiled and the katorzhnye up until February $1917^{20}$. From early on, preserving the corporal punishment of the exiles and katorzhnye was argued for with the the fact that, according to the head of the Second Section of his Imperial Majesty's Own Chancery Count D.N. Bludov, "such exiles are already civilly dead [and that] means that corporal punishment is practically the only means by which the justice system can penalize" those who committed further offences while in exile"21. The severest types of the corporal punishment for the convicts (lash, sticks and running the gauntlet) were only abolished on $3 \mathrm{June} 1903^{22}$. Political prisoners were generally exempt from corporal punishments until 1888. George Kennan remarked that this exemption from lashing and birching was not regulated by any legal acts, but rather by the social norms: in the last decades of the nineteenth century the majority of political prisoners were noble, and the prison doctors have allegedly routinely exempted them from punishment by attesting that the prisoners were not in good enough health condition to survive the beating ${ }^{23}$.

Apart from the corporal punishment, the Imperial penal system heavily relied on exile: it was not only a criminal punishment for more serious wrongdoings, but also an administrative measure that could allow the landlords and the urban and rural communities to expel the "undesirables". For most history of the Russian Empire, exile preceded incarceration in the role of the dominant penal practice; it implied a different organizational structure of punishment and also distinctive underlying ideas that largely relied upon the imperative of colonization. Even with the growing importance of imprisonment, exile was far from disappearing.

\footnotetext{
${ }^{20}$ ISAEV, Maksim. Osnovy penitentsiarnoi politiki. M oscow: Gosizdat, 1926, p. 87.

${ }^{21}$ SCHRADER, Abby M. The Languages of the Lash: the Russian Autocracy and the Reform of Corporal Punishment, 1817-1893. PhD. dissertation. University of Pennsylvania, 1996, p. 211.

${ }^{22}$ RGIA, f.1151, op.15, d. 196, I. 2.

${ }^{23}$ KENNAN, George. Siberia and the Exile System. New York: Century CO, 1891, vol. 2, p. 262.
} 
Prior to creation of the GTU, some of the civil prisons were supervised by the Russian Prison Aid Society (Popechitelnoe Obschestvo o tiurmakh, or POoT). It was a charitable association of gentry founded in 1819 in Saint-Petersburg. This association soon opened up local committees in other important cities of the empire, generally putting a strong emphasis on the religious education of prisoners. Its members otherwise rarely sought to improve the physical and social condition of prisoners, apart from several exceptionally active philanthropists ${ }^{24}$. With time, the POOT was completely overtaken by apathy and did not undertake any attempts to make changes to the prison system ${ }^{25}$, and when the M inistry of internal affairs started to take action against the deplorable condition of Imperial prisons, the minister did not turn to the POoT, but addressed the Ministry's own Department of Executive Police ${ }^{26}$ instead.

Unlike the POOT, the Main Prison Administration proclaimed that it would organize the places of confinement along the "rational" principles, and the introduction of the obligatory labour of prisoners was a cornerstone of these transformations ${ }^{27}$. These principles were embodied in the GTU's practice that included research into the prison and exile condition in the Empire ${ }^{28}$, continuous collection of uniform statistical information from the regional prisons ${ }^{29}$, standardization of the everyday life in prison aimed both at prevention of escapes and the improvement of prisoners' condition ${ }^{30}$, participation in the International prison congresses and dissemination of theoretical knowledge about prisons (that would, eventually, facilitate the professionalization of the prison wardens). This innovative, "scientific" and "creative" approach is stressed in major GTU publications ${ }^{31}$. By incorporating international research in "penology" (tiurmovedenie), exploring the state of the local

\footnotetext{
${ }^{24}$ ADAM S. Op. Cit., p. 40-41.

${ }^{25}$ KRAINSKII, Dmitrii. Materialy $\mathrm{k}$ issledovaniiu istorii russkikh tiurem $v$ sviazi $s$ istoriei uchrezhdeniia Obschestva popechitelnogo o tiurmakh. Chernigov, 1912, p. 85-86.

${ }^{26}$ ADAMS. Op. Cit., p. 45.

${ }^{27}$ KRASOVSKY, M. 0 zaniatii arestantov rabotami v russkikh tiurmakh. Tiuremnii vestnik, 1897, no. 11, p. 514.

${ }^{28}$ Tiuremnii vestnik, 1914, no.2, p. 300.

${ }^{29}$ These were published in the annual reports of the Main Prison Administration (Otchety Glavnogo tiuremnogo upravleniia).

${ }^{30}$ This happened through the implementation of the circulars of the Main Prison Administration, later published in a two-volume collection: Sbornik tsirkuliarov po Glavnomu tiuremnomu upravleniiu v 18791910. Saint- Petersburg: Glavnoe tiuremnoe upravlenie, 1911.

${ }^{31}$ This is most salient in the report of the first ten years of the GTU's activity: Obzor desiatiletnei deiiatelnosti Glavnogo tiuremnogo upravleniia, 1879-1889. Saint-Petersburg, 1889, but it is also visible in the publications of "The Prison Herald".
} 
prisons, and quantifying the material aspects of imprisonment, the officials of the GTU sought to create new, experience-based knowledge of the imperial prisons. The aspirations to improve the state of prisons through better knowing the prison condition in practice sometimes translated into the measures that were palliative rather than transformative. For example, one of the major issues for the GTU in the early 1880s was the organization of the manufacturing of the prison uniforms. Precise patterns were sent out to the prison officials, and every imaginable aspect of these uniforms was described in lengthy instructions. In other words, the GTU officials were sometimes concentrating on the issues that could be tackled through measurements and prescription.

The GTU officials faced the challenge of creating a modern prison which would at the same time fit accordingly in the Russian context. According to them, this context was chiefly defined by the lack of financial support of prisons and the absence of the coherent legislation and the central administrative body, and right from 1879 these officials embarked on a journey to tackle these issues. Employees the Main Prison Administration rarely hesitated to underline in their reports that most of the problems of Russian prisons were engendered by a consistent lack of funds. Before 1879, the local governors were supposed to manage the prisons and to solicit financial help from the Ministry of Finance; between 1875 and 1879, they received on average just half of the sum they asked for for the prison maintenance. In 1879 the lack of money was particularly salient: the estimate of the expenses was 737000 roubles, while only the amount of 177505 roubles was allocated ${ }^{32}$.

However, financial deficit constituted just a fraction of the obstacles that thwarted the advance of the reform. The truly defining features of the Russian context of that time seem to have been far beyond the range of action of the GTU: the existence of the system of exile and, and on the bigger scale, the practices of governance that made it possible; the existence of the two separated "ladders of punishment" for the nobility and everyone else and, more broadly, the profound social inequality between the elite and the rest of the population; the logistical difficulties of the organization of prisons, namely the lack of the well-trained officials.

${ }^{32}$ Obzor desiatiletnei deiiatelnosti Glavnogo tiuremnogo upravleniia, 1879-1889. Saint-Petersburg, 1889, p. 7. 


\section{Profile of an Official: Mikhail Galkin-Vraskoi}

The reform of 1879 , as I already mentioned, opted for a new organization of prison management rather than an immediate transformation of prison condition. This was why the reform took shape over the course of several decades, and this shape was largely defined by the executives of the Main Prison Administration, and most notably Mikhail Galkin-Vraskoi (1832-1916), who became its first, and longest-serving, director. This part explores the connections between the shape of the prison reform and the administrative practices of the late Imperial period. Administrative career of Mikhail Galkin-Vraskoi allows to trace the emergence of some of the new practices of prison management.

The knowledge-based approach to prison governance was crucial for the transformation of the penal system in the last decades of the nineteenth century. It allowed to reinforce control over the prisoners, and eventually to improve their condition. This desire to solve governmental problems with the help of the new, "rational", science-based principles germinated within a limited group of administrators and was proper to other official outside of the GTU as well. Such approach, combined with "an independent sense of identity and purpose" ${ }^{33}$, characterized such Imperial administrative institutions as the Financial Ministry ${ }^{34}$ and the Main administration of land management and agriculture ${ }^{35}$. Alfred Rieber suggested that these Imperial officials reached an unprecedented degree of cohesion in their actions: "There is the same sense of moral identity as experts, the same dedication to introducing science or special knowledge into life, the same corporate pride in achievement and mastery of problems ${ }^{136}$.

It is not possible to estimate to which degree this knowledge-based approach to the prison management was implemented in the prisons throughout the Empire; the traditional penal conceptions and practices still lingered powerfully, and after the revolution of 1905 the desire of central authorities to instrumentalise penal system as

\footnotetext{
${ }^{33}$ HOLQUIST, Peter. In Accord with State Interests and the People's Wishes: The Technocratic Ideology of Imperial Russia's Resettlement Administration. Slavic Review, 69, no. 1. spring 2010, p. 152.

${ }^{34}$ RIEBER, Alfred. Bureaucratic Politics in Imperial Russia. Social Science History, 2, no. 4, p. 399-413, Summer 1978.

35 HOLQUIST, op.cit.

${ }^{36}$ RIEBER, Alfred. Patronage and Professionalism: The Witte System. In: ANANICH, B. V. Problemy vsemirnoi istorii: Sbornik statei v chest Aleksandra Aleksandrovicha Fursenko. Saint-Petersburg, 2000, p. 291.
} 
a tool against political dissent prevailed over administrative considerations. Nevertheless, over the course of three decades the knowledge-based approach to prisons has profoundly transformed the practices of incarceration in the Russian Empire.

Certain managerial and conceptual innovations that were later incorporated in the prison reform can be traced back to the precise moments of experimentation. One of the officials whose activity has been marked by such experimentation was Mikhail Galkin-Vraskoi. Galkin-Vraskoi did not attract as much attention as other prominent officials of the Late Imperial politics ${ }^{37}$, but his political trajectory shows that he was firmly embedded within the political elite and was able to build a career that spanned over several decades and apexed in obtaining a seat in the State Council in 1896. Moreover, his judgment was pivotal for the prison reform: having become the first head of the Main Prison Administration in 1879, he remained in this position for seventeen formative years. Peter Kropotkin, one of the most attentive observers of Russian prison situation, noted in 1890 that "all has been centralized in M.GalkinWrassky's (sic) own hands"38.

Galkin-Vraskoi was a typical representative of the late Imperial governmental elite in two important ways: first, he belonged to nobility, and second, his trajectory demonstrates the attempts to develop the rational bureaucratic governance. In the last decades of the nineteenth century the core group of Imperial government mostly consisted of career civil servants: "a few key figures in government were military or naval officers, or even indeed professors and businessmen"39. Mikhail Galkin-Vraskoi's career as a civil servant started in the diplomatic service, and he spent several years in Central Asia. During this work, he also collected ethnographic information about the Turkmen people, and published an article about them upon return to Moscow ${ }^{40}$. As a member of the Russian Geographic Society, he participated in the production of imperial knowledge about the borderlands; during his two-year-long stay in Western

\footnotetext{
${ }^{37}$ To the date, the only monograph on the life of Galkin-Vraskoi and his role as the head of the GTU was published by a Russian historian S. Zubov in 2007: ZUBOV, Serguei. M.N. Galkin-Vraskoi - nachalnik Glavnogo Tiuremnogo upravleniia Rossiiskoi Imperii (1879-1896 gg.). Saratov, 2007.

${ }^{38}$ KROPOTKIN, Peter. Russian Prisons in an Official Report, The Times, 1890, June 6.

39 LIEVEN, Dominic. Russia's Rulers Under the Old Regime. New Haven and London: Yale University Press, 1990, p. 121.

${ }^{40}$ GALKIN, Mikhail. Etnograficheskie materialy po Srednei Azii i Orenburgskomu kraiu. Saint-Petersburg, 1868.
} 
Europe, he demonstrated a similarly investigative approach of information collection and systematization towards a new subject: the prisons. Upon return to Russia, he published the first Russian-language research on the contemporaneous Western European prisons, describing the condition of prisons in Switzerland, Belgium, and France ${ }^{41}$. He visited, among others, the famous Mettray penal colony. His interest in prisons did not remain purely theoretical: upon return from Europe in 1864, GalkinVraskoi started to participate in the activity of the POOT in Saint-Petersburg already in 1865. By the end of 1867, he became the warden of the experimental Saint-Petersburg prison. This experimental prison had a twin institution in Moscow, the corrective workhouse headed by count Sollogub, who several years after that would chair the commission for the preparation of the prison reform. The Saint-Petersburg prison was organized exclusively for the prisoners serving the terms of up to one year ${ }^{42}$. This prison served as a laboratory of the penological innovation: it was the first institution in the Russian Empire where night-time separation and remunerated labour for common prisoners (outside of the workhouses) were introduced. Indeed, already in 1868 GalkinVraskoi outlined what seems to have remained the mission of the GTU in the next decades: "People leaving the prisons returned to the society either being completely sick and therefore incapable of performing any labour, or having become even more corrupt and criminal than they were before their incarceration: prison became for them either a physical infection [zaraza] or an ultimate school of crime of all sorts"43. This quote marks the two main challenges that the officials of the GTU sought to tackle: on the one hand, they faced a pressing need to improve the physical condition of the prisoners, and on the other, prevent the recidivism by "reeducating" the prisoners.

The Saint-Petersburg prison was lauded by the higher officials and generally considered a successful experiment of implementation of obligatory labour in prisons ${ }^{44}$. However, it started to decay as soon as Galkin-Vraskoi left it: after six months of service as a prison warden, he was appointed the governor of Estland and spent almost two years there. However, the veritable long-running experimentation started when he became the governor of Saratov region 1870. There he not only experimented with the

\footnotetext{
${ }^{41}$ GALKIN, M ikhail. M aterialy k izucheniiu tiuremnogo voprosa. Saint- Petersburg, 1868.

${ }^{42}$ GALKIN, Mikhail. Ibidem, p. 167.

${ }^{43}$ GALKIN, Mikhail. Ibidem, p. 7-8.

${ }^{44}$ ZUBOV, Serguei. Op. Cit., p. 16.
} 
prison conditions, but also raised money for the organization of an "instructivecorrective shelter" (uchebno-ispravitelnii dom), which was opened in 187345. It was a penal colony for the juvenile offenders, and its shape was certainly inspired by the Mettray colony. In Saratov, however, both boys and girls were detained; they were to perform not only the agricultural, but also artisanal work. The type of labour they had to perform was gender-specific: the boys were to be taught the trades of shoemaking, carpentry or locksmithing, and the girls were to study knitting, sewing and performing household chores. This colony was not the first one in Empire, but for Galkin-Vraskoi it was the first immediate opportunity to supervise over an extended period of time the disciplining effects of labour over the inmates. The same disciplining measures would be used for the adult detainees: under Galkin-Vraskoi's governance, the Saratov prison became the second place in the Russian Empire where prisoners would receive payment for the labour they performed, the first one being the Saint-Petersburg experimental prison he headed in 1867-68.

Indeed, the remuneration of convict labour marks the rupture with the other type of forced convict labour, the katorga. It reflects the ideal of rehabilitation of convicts through labour and the compelling ideal of the industrial wage labour: performing labour and receiving remuneration for it, according to the GTU officials, not only disciplined the prisoners within the prison walls, but also facilitated an easier reintegration into society after the release.

Galkin-Vraskoi, however, was not concentrated uniquely on the implementation of obligatory reformatory labour for the prisoners serving shorter terms. Perhaps the most well-known penal project that he promoted during his term as the head of the Main Prison Administration was the establishment of penal colony on Sakhalin. Sakhalin, the easternmost island of the Russian Empire, became a penal colony in 1869. This hard labour colony - katorga - existed until the 1905 Russo-Japanese war, when the convicts were evacuated and distributed in various locations in Siberia. Without seeking to reform the katorga as penal institution in general, officials founded the Sakhalin colony both as a place of punishment and as an instrument of colonization by the means of populating it with the convicts serving long terms and

${ }^{45}$ ZUBOV, Op. Cit., p. 17. 
sentenced to life-long exile ${ }^{46}$. The overlap of these two goals produced a peculiar katorga site: "The penal colonies on Sakhalin itself were to be more than simply places of labor, but were designed to function as reformatories, exerting social control over convicts and molding them into law-abiding citizens" ${ }^{47}$. However, in contrast with the project of reformatory labour of prisoners serving shorter terms, penal colonization of Sakhalin proved to be a failure ${ }^{48}$, largely due to the fact that it was conceived as an agricultural colony, while the yield of the agricultural works was doomed to be extremely meager due to climatic conditions. Even the GTU admitted in its 1899 report that "Sakhalin's climate cannot be considered fully suitable for farming and favorable for development and prosperity of an agricultural colony ${ }^{449}$. However, even in 1894, one of the last years of his service as the head of the GTU, Galkin-Vraskoi was still positive about this experiment. He traveled to Sakhalin and inspected the colony, but "made few attempts to look beyond what he was shown"50 and in his report he stated that the colony needed some minor adjustments and further funding ${ }^{51}$; indeed, he remained supportive of this project even as the successive head of the GTU started to harshly criticize the colony ${ }^{52}$.

This brief outline of the trajectory of the most prominent Imperial prison executive allows me to make two crucial observations concerning the development of the prison administration in the last decades of the nineteenth century.

First, Galkin-Vraskoi's trajectory demonstrates nascent professionalization of the prison administration: continuous field research on various penal institutions together with the hands-on experimental approach to management would both

\footnotetext{
${ }^{46}$ Polnoe sobranie zakonov rossiiskoi imperii, series II, vol. 44 (1869), no. 46984, p. 330-333.

${ }^{47}$ CORRADO, Sharyl M. The "End of the Earth": Sakhalin Island in the Russian Imperial Imagination, 1849-1906. PhD. dissertation, University of Illinois at Urbana-Champaign, 2010, p.9.

${ }^{48}$ Most well-known contemporary critic of penal colony on Sakhalin was, of course, Anton Chekhov: CHEKHOV, Anton. Sakhalin Island. London: Oneworld Classics, 2007 (First published in Russian in 1895), but in the end of the nineteenth century several reports were published criticising Sakhalin, including one by jurist Dmitrii Dril: DRIL, Dmitrii. Ssylka vo Frantsii i v Rossii: iz lichnykh nabliudenii vo vremia poezdki v Novuiu Kaledoniiu, na 0. Sakhalin, v Priamurskii krai i Sibir. Saint-Petersburg: L. F. Panetella, 1899. One of Galkin-Vraskoi's successors on the post of the head of the GTU, Alexandr Salomon, was equally critical of this experiment: SALOMON, Alexandr Petrovich. O. Sakhalin (Iz otcheta byvshego nachal nika glavnogo tiuremnogo upravleniia A.P. Salomona). Tiuremnyi vestnik, 1901, №1, p. 20-53.

${ }^{49}$ Otchet po Glavnomu tiuremnomu upravleniiu za 1899 god. Saint- Petersburg, 1901, p. 105.

${ }^{50}$ CORRADO, Sharyl. Op. Cit., p. 117.

${ }^{51}$ GALKIN-VRASKOI, Mikhail. Ostrov Sakhalin. Neobkhodimye i zhelatelnye meropriiatiia. Zapiska byvshego nachalnika Glavnogo tiuremnogo upravleniia Deistvitelnogo tainogo sovetnika GalkinaVraskogo po obozreniiu ostrova Sakhalina v 1894 godu. Saint-Petersburg, 1899.

${ }^{52}$ SALOM ON, Alexandr Petrovich. Op. Cit., p. 20-53.
} 
become the bedrock of the GTU's activity. In his research on the members of the State Council Dominic Lieven ${ }^{53}$ underscored the importance of education and hands-on experience of management for the high-ranking Imperial officials. Moreover, in an exploration of the ensemble of the general-governors in the last years of Russian Empire, Richard G. Robbins observed that there existed signs "that point to growing skill and a real, albeit limited, professionalization" ${ }^{54}$. The degree of this professionalization and the overall proficiency of the late Imperial bureaucrats, however, are still to be explored on a bigger scale, as collective biographies of the high officials still provide insights that concern only a very restrictive group of officials. It seems that the observations of Lieven and Robbins complement rather than contradict the earlier suggestion of Marc Raeff about Russia's "lack of a homogeneous, effective, and powerful bureaucracy" 55 .

Second, the story of organization of the penal colony on the island of Sakhalin exposes the inherent problems of centralization and concentration of power typical for the imperial bureaucracy: namely, the problems of information circulation, and the fact that all possibilities to check Galkin-Vraskoi's power were reserved to the higherranking officials.

\section{The New Conceptions of Convict Labour}

Until the last decades of the nineteenth century the labour of convicts was conceived first and foremost as punishment, therefore implying hard physical labour as its primary form. The penal regime that was shaped by this idea was the katorga: originating as a way to use the convict labour for the state shipbuilding sites in the early eighteenth century ${ }^{56}$, it has developed over several decades to become the harshest punishment for the common criminals in the Russian Empire. Prior to 1845 the katorzhnye were branded, that is, physically stigmatized for life, but even after the abolition of branding katorga would leave irreversible traces on the bodies and mind of

\footnotetext{
${ }^{53}$ LIEVEN, Dominic. Russia's Rulers Under the Old Regime. New Haven and London: Yale University Press, 1990.

${ }^{54}$ ROBBINS, Richard G., Jr. The Tsar's Viceroys. Ithaca and London: Cornell University Press, 1987, p. 240 241.

${ }^{55}$ RAEFF, Marc. The Russian Autocracy and Its Officials. In: MCLEAN, Hugh et al. (org.). Russian Thought and Politics. Cambridge: Harvard University Press, 1957, p.78.

${ }^{56}$ M ARGOLIS, Aleksandr. Tiurma i ssylka v imperatorskoi Rossii. M oscow: Laterna Vita, 1995, p. 7-10.
} 
the convicts, leaving them exhausted and broken ${ }^{57}$. The idea of katorga implied extremely hard physical labour, frequently under dangerous conditions (such as work in the lead or silver mines), without any remuneration, combined with being locked in shackles. The work of convicts as it was conceived by the GTU, however, had a completely different idea of punishment in its foundation and entailed a very different set of practices. The process of knowledge production about this new type of labour is the focus of this part.

The shift of the modalities of convict labour in the Russian Empire occurred during the last third of the nineteenth century. Over this time, and up until the end of the empire, the obligatory "rehabilitative" prison labour that debuted in the experimental prisons in the capitals started to acquire growing significance in the regions as well. This labour was intended to become an integral part of imprisonment, and, unlike the primarily punitive katorga labour, it was conceptualized as a scienceand practice-based way of reforming the convicts which at the same time would enable deriving derive profit from their work ${ }^{58}$. The Main Prison Administration continuously advanced this type of labour, and it is necessary to look at it in detail not only because of its contemporary importance, but also because some of its elements bear resemblance with certain practices of forced labour in the Soviet labour camps. This resemblance is most visible on the organizational level: introduction of remuneration (however meager), the daily norms of work to fulfill (in the form of uroki) and the preoccupation with production were all first introduced during this time. Unarguably, these practices were continuously transformed, and took a much more violent twist during the Soviet times, but it is nevertheless crucial for a historical study to acknowledge their origin and account for their gradual constitution. Moreover, very much like the Soviet officials several decades later, the GTU officials of the turn of the century would also make a strong connection between the universal (convict) labour and the benefit of the society at large: "in a correctly organized society not a single

\footnotetext{
${ }^{57}$ BADCOCK, Sarah. From villains to victims: experiencing illness in Siberian exile. Europe- Asia Studies, $n$. 65 (9), p. 1716-1736, 2013.

${ }^{58}$ GARF (State Archive of the Russian Federation, Moscow), f.122 op. 7 d. 215 I.77 (1886) and the following pages.
} 
healthy and able-bodied member should count on the privilege of being exonerated from the labour that is obligatory for everyone ${ }^{159}$.

The obligatory convict labour could take various forms, and none of them ever became fully dominant throughout the whole Empire; in the beginning, the extramural works were favored, as they were supposed to be beneficial for the convicts' health ${ }^{60}$. However, this type of work required extra guards and often facilitated the escapes. Some of the first actions of the GTU sought to fight the escapes by increasing the number of guards and improving their working conditions ${ }^{61}$.

An attentive reading of the most important law concerning the introduction of obligatory convict labour suggests some inherent problems of the GTU's modus operandi. It clarifies, on the one hand, the pace and the shape of the uneasy introduction of obligatory labour, and, on the other, the ideas behind this "rehabilitative" type of labour. Leaving aside various consequences of this legal act, here I study it "in terms of the forms through which [its] authority was established"62. In order to trace these forms, I have already looked at some of the agents of change, and now I bring into the picture some of legal documents they produced.

The legal act that introduced obligatory labour for all convicts in the Russian Empire was the law 6 January $1886^{63}$. This law stated three chief principles of the prison labour: 1) its compulsory character for most categories of prisoners (except for those inmates who were under arrest and those who were awaiting the trial); 2) remuneration of the convicts for their work; 3 ) responsibility of the prison wardens for the implementation of this law. This last point, the delegation of responsibility for its implementation proved to contribute to the fragmented advance of the reform. The first paragraph of the law of states that the organization of the convict labour becomes a part of the responsibilities of the local prison keepers: in the case of prisons supervised by the POOT, Popechitelnoe Obshchestvo o Tiurmakh, the local committees of this society were responsible for the organization of convict labour; in other cases, the prison wardens were to organize the work. However, the failure to comply with this

\footnotetext{
59 LUCHINSKII, Nikolai. Arestantskie raboty vo Frantsii i v Rossii. Tiuremnii vestnik, 1906, №1, p. 40.

${ }^{60}$ ZUBOV. Op. Cit., p. 27.

${ }^{61}$ Obzor desiatiletnei deiiatelnosti Glavnogo tiuremnogo upravleniia, 1879-1889. Saint-Petersburg, 1889, p.68-100.

${ }^{62}$ DAS, Veena. Subaltern as Perspective. Subaltern Studies, vol VI, 1989, p. 317.

${ }^{63}$ Polnoe sobranie zakonov Rossiiskoi imperii, series III, vol. 6 (1886), no. 5447, p. 8- 11.
} 
new legislation did not entail any legal or administrative consequences. This law, marked by the typical meticulousness of the jurists, enumerates all the categories of convicts that were liable to obligatory labour and gives a detailed account of the working times, civil and religious holidays. However, the precise guidelines for the organization of the convict labour were absent. Only two paragraphs out of twenty five attempt to propose a framework for the organization of convict labour. Paragraph number ten states: "The forthcoming definition of types of work that the convicts can perform either following the order of the prison wardens or according to their own will is going to be conducted by the Main Prison Administration". Preceding this, paragraph number nine announces that this work can be performed both within and without the prison walls.

Unsurprisingly, this law required extensive explanations and precisions. Over the following years, the circulars of the Main Prison Administration sought to extend and refine the guidelines for the organization of convict labour. Not only the legal acts, but also the later publications in the the official magazine of the GTU concerning the forced labour continuously affirmed that its organization had to be initiated by the prison bosses (nachalniki tiurem) and the local general-governors. At the same time, other publications, namely, the circulars, testimony that at least in the beginning the idea of the obligatory labour of the prisoners was interpreted and implemented by the local wardens not quite as the central officials expected. One of this documents, an official circular of the GTU dating back to March 1888, states: "The GTU always implied that the most preferable type of prison work should be the work within the prison facilities, in the cells or in the workshops, as the only ones fully conforming to the notion of deprivation of liberty, and always recommended to direct the convicts towards the extramural work only because of the countrywide (povsemestnoe) overpopulation of prisons, the lack of workshop facilities and as a means of preventing the absolute idleness of the convicts"64.

This introduction of obligatory labour was to be realized locally, without much logistical assistance from the central administration. Most of the documents the GTU produced concerning this matter were of prescriptive character and were addressed to the local prison wardens: in other words, instead of training or organizing the prison

${ }^{64}$ GARF f.122 op.7 d.215, l.130 and the following pages. 
personnel, the officials of the Main Prison Administration concentrated primarily on dissemination of the theoretical knowledge about the newly conceptualized obligatory prison labour, generally by the means of circulars and publications in the professional journal, "The Prison Herald" (Tiuremnii vestnik). More than a decade after the introduction of the obligatory convict labour there was still no central department that would direct its implementation, and, as suggested by one of the authors of "The Prison Herald", this thwarted the process ${ }^{65}$. The experimental prisons described earlier were the showcase examples of the benefits of the obligatory labour, but the reproduction of this experience in other prisons has proved to be slow and limited. Describing the period between the creation of GTU and the introduction of obligatory labour for all convicts (1879-1886), the minister of Interior D. Tolstoy noticed: "in those cases where the aspirations of the central administration met with the desire of the local agents (deiiatel), the affair of organization of the convict labour attained noticeable results" ${ }^{n 6}$. Ostensibly, in other cases the organization of convict labour could be quasi nonexistent.

Publications that have appeared over the last third of the nineteenth century in the official journal of the Main Prison Administration help to trace the nuances of the new conceptions of forced labour. These publications typically combine overviews of the situation around forced labour in Russia, appeals to the Western European experience, and some propositions for the improvement of the situation in prisons. These voices included prison wardens ${ }^{67}$, professors of law ${ }^{68}$, the GTU officials, and others ${ }^{69}$.

Unlike the final legal documents, these articles help to unravel the dynamic and creative process of trial and error that defined the style of Russian prison administration of last decades of existence of the Empire. Taken all together, they also show that the Imperial penal system has been continuously characterized by fragmentation, unspoken rules, and the decisions that were guided by the political

\footnotetext{
${ }^{65}$ KRASOVSKY, M. 0 zaniatii arestantov rabotami v russkikh tiurmakh. Tiuremnii vestnik, 1897, №11, p. 521.

${ }^{66}$ GARF f.122 op. 7 d. 215 I.77.

${ }^{67}$ VIKHAREV. Arestanstkie raboty. Tiuremnii vestnik, 1895, №8, p. 430-432.

${ }^{68}$ GOGEL, Serguei. Arestanstkii trud. Tiuremnii vestnik, 1913, №2, p. 297-333.

${ }^{69}$ For example, publicist A.P. Aksakov: AKSAKOV, Aleksandr. Trud kak orudie nravstvennogo vozrozhdeniia. Tiuremnii vestnik, 1903, № 5 (p. 382-407) and №6 (p. 471-502).
} 
rather than purely legal considerations. These texts address similar issues: what are the benefits of the convict labour? What role does it have to play in the organization of prisons and what functions should it have? How should the prison labour be organized? What types of work should the convicts perform? These questions are related to the specificity of the reform: a considerable part of the penological innovation at that time was related to the prison buildings and defined the shape of the cells and the workshops.

These reflexions were embedded within the dominant discourse on crime and punishment, with morality of criminals situated in the center of these discussions. Concentration on morality was often occluding the inherent problems of midnineteenth century incarceration and exile: overpopulation and the inevitable and potentially dangerous close contact of prisoners, the necessity for the families to follow the exiles and the katorzhnye to Siberia, the general absence of sources of income for either prisoners or their families. These articles also illustrate the attempts to synthesize a viable penal system that would incorporate both the forms of punishment borrowed from the Western European contexts and the existing Imperial practices. In 1906 one of the officials of the GTU colorfully alluded to this conflict in the following way: "In reality, these two currents (that we are going to call "historical" and "rational"), as they collide, produce nothing but a whirlpool where dies all the good will and any good initiative (pochin)"70. Abby M. Schrader noted the same tension between the traditionally Russian penal practices and the Western European legal norms already for a much earlier period, namely the 1850s. She states: "although Russian officials ostensibly only took into account Russian precedents and Russia's organic historical development when compiling penal legislation, the process by which they developed this notion of physical difference shows that they incorporated Western European laws when deciding whose bodies to spare punishment"71.

Judging from the publications in "The Prison Herald", the attempts to rely on the initiative and knowledge of the local officials delivered very limited results. We see many more general and theoretical discussions of the prison labour than reports from

\footnotetext{
70 LUCHINSKII, Nikolai. Arestantskie raboty vo Frantsii i v Rossii. Tiuremnii vestnik, 1906, №1, p. 49.

${ }^{71}$ SCHRADER, Abby M. PhD. diss., p. 237.
} 
the local prisons. The warden of a local prison in the region of Smolensk, P. Vikharev ${ }^{72}$, published in 1895 a short article on the labour of prisoners. Adhering to the general view within the GTU, he suggested that the convicts should not be taken to work outside the prisons, as it reduces the punitive effects of incarceration ${ }^{73}$. The only type of the work outside the prison that Vikharev favored was the agricultural labour. He was one of the rare writers who have directly connected the prison labour with the type of work that was the most common in the Empire. He also suggested that this would be consequently beneficial for the prisoners, as most of them were coming from peasantry and would find this type of work both familiar and inherently useful. Guided by his experience of managing a prison in a relatively densely populated region, he was putting forward the idea of letting the peasants hire the convicts during the summer season, when, according to him, the work of the free wage workers was unaffordable for most of the peasants ${ }^{74}$.

Vikharev also addressed the issue of the intramural work, and he was very precise about the type of work that should be favored: it was the basket weaving and making of the bast shoes, and all types of work with the bast fiber in general, as this type of labour required quite primitive skills, and yet produced widely needed and easily marketable goods.

Introduction of the obligatory prison labour for shorter-term ${ }^{75}$ convicts went in parallel with the forced labour for the prisoners with longer terms. This other type of the forced labour, the katorga, was not abandoned by the administrators either, but it was developing very differently. The main experiment with katorga was the installation of a katorga site on Sakhalin island. It was an important imperial project that had lingering negative effects both on katorga as a type of punishment and the development of the region.

\footnotetext{
72 VIKHAREV. Arestanstkie raboty. Tiuremnii vestnik, 1895, №8, p. 430-432. The prison that Vikharev was administrating was an uyezd prison, that is, it belonged in a town of several thousand inhabitants. The uyezd was a secondary-level administrative subdivision in Imperial Russia. Generally, the short-term detainees were incarcerated in such smaller regional prisons.

73 Ibidem, p. 431.

${ }^{74}$ Ibidem, p. 432.

${ }^{75}$ According to the 1890 prison regulations (Ustav o soderzhaschikhsia pod strazhei), people could be sentenced to prison terms of up to two years. There existed another type of punishment, incarceration in the "corrective arrest divisions" (ispravitelnie arestantskie otdeleniia) that implied terms of up to six years. In contrast, those sentenced to katorga faced terms from 4 to 20 years.
} 
For most of the nineteenth century, forced labour of convicts in Russia was not regulated in a straightforward way: the law (Ustav o soderzhaschikhsia pod strazhei) was full of lacunae concerning labour of prisoners $^{76}$, and that created a contradictory landscape of the penal labour throughout the Russian Empire. Traditionally, the chief category of convicts forced to works were those sentenced to katorga, but the inmates of the workhouses, for example, also had to work and would even receive payment for their labour. Prison inmates, on the other hand, could make the decision about work in prisons themselves and were not remunerated. Prior to 1886, starting from the $1860 \mathrm{~s}$, two different processes were at play in the unequal development of the convict labour. On the one hand, some workshops within prisons were organized in the regions with the higher density of population. Ostensibly, the development of the smaller workshops was connected with the overall industrial development of the surrounding region: it was the initiative of the prison keepers to organize them, which they would do only if there existed an opportunity for them to derive profit from convict work. This was the case, for instance, of the experimental prisons in Saint-Petersburg, Moscow and Saratov that I already mentioned before. This particular form of labour would later be promoted by the GTU to become the most important one, yet the organization of these workshops was heavily embedded in the local contexts: it required well-prepared officials and instructors and the markets for the items produced by the convict labourers. While reflecting on the 1860 s as the period of the crisis of the Imperial penal system, the GTU officials presented the convict labour at that time as an ultimately fragile enterprise: in some regions, like the more densely populated Western borderlands of the Empire, the workshops in prisons existed in the first half of the nineteenth century, but in the 1860s, confronted with the prison overpopulation, the local prison keepers transformed them into cells ${ }^{77}$.

On the other hand, the forced labour has also been developing in the Eastern Siberia, most notably at the katorga sites in Transbaikalia that were typically silver mines belonging to the Emperor (the most well-known of them is Nerchinsk). This type of organization of the convict labour was guided by the profit of the Emperor, rather

\footnotetext{
${ }^{76}$ KRASOVSKY, M. 0 zaniatii arestantov rabotami v russkikh tiurmakh. Tiuremnii vestnik, 1897, №11, p. 514.

77 Obzor desiatiletnei deiiatelnosti Glavnogo tiuremnogo upravleniia, 1879-1889. Saint-Petersburg, 1889, p. 7.
} 
than the local prison officials, and implied concentration of labour force. It was applied in the regions where labour shortage existed and the state desperately needed workforce for extraction of resources. Such a way of exploitation of convict labour required a higher amount of guards but less sophisticated managing skills, and generally implied much harder work than that in the workshops. Such work in mining was the main type of katorga labour before the installation of the katorga facilities on the Sakhalin island in 1869 (where agricultural and road construction work were favoured), and continued to exist in Siberia.

These are the two contradictory trends reflecting different ideological underpinnings of the prison labour. Theoretically, modernization of the prison system as it was conceived by the GTU did not leave much space for the big, katorga-style facilities like mines: both its officials and the experts not affiliated with the GTU have been consistently putting forward the idea of prison workshops that would be small, decentralized, and well-inscribed in local conditions. In practice, however, even though the organization of katorga labour was in utter decay since the beginning of $1860 \mathrm{~s}^{78}$, katorga was still widely used as punishment and coexisted with the new types of punishment up until the revolution of 1917.

The legislation in the domain of katorga seems to have been lagging behind the practice. For example, the distinction between fortresses (kreposti), plants (zavody) and mines (rudniki) as traditional sites for katorga originated in the eighteenth century; these sites were graded according to the hardship of punishment, plants being the sites of the "lightest"79 punishment, and the mines that of the harshest. Most of these traditional sites that hosted the katorzhnye have already been abandoned by the end of 1860 s, but this distinction existed in the legislation until $1885^{80}$, despite the fact that the first attempts to change it dated back to $1868^{81}$. Katorga proved to be a particularly sticky penal practice: it survived without any consistent reform until the end of the empire. Despite the significant change of the condition of the common

\footnotetext{
${ }^{78}$ M AKSIM OV, Serguei. Sibir i katorga. Saint- Petersburg, 1900.

${ }^{79}$ Notions of "light" and "harsh" punishment in the case of katorga do not reflect any clear-cut differentiation. In practice, observers (most notably, Maksimov) have noticed that some types of the plants proved to be deadly for the inmates.

${ }^{80}$ RGIA f.1405 op.85. d.3014. I.23.

${ }^{81}$ RGIA f.1405 op.85. d.3014. I.3.
} 
prisoners, the main traits of katorga remained fairly catastrophic for the convicts, as the Sakhalin experiment ${ }^{82}$ has shown. The situation of katorzhnye who were detained in the European part of Russia could be very different, but equally distant from the condition prescribed by the documents.

Smaller workshops within prisons were the type of the prison labour that the GTU has generally favored, but it is not possible to assess numerically the scope of its implementation; it was, most certainly, limited. According to the GTU reports, the profit from the convict work has been steadily growing from 1887 to 1895, with extramural work generally bringing more profit than the work in the workshops or the maintenance work within prisons ${ }^{83}$. At the same time, the GTU admitted that the allencompassing statistical data were missing.

It seems that in the last years of Empire, the idea of organizing workshops and producing locally marketable goods prevailed even among some katorga prison wardens: at least, this was the case of the Tobolsk katorga prison. When a criticallyminded young jurist Maksim Isaev lamented the disarray in the katorga prisons throughout the empire, he singled out the Tobolsk katorga prison no.1 as the only one that had the convict labour organized "in a partially satisfactory manner" ${ }^{\text {"4 }}$. From the archival documents we see that this prison hosted a brick factory that achieved consistent profitability ${ }^{85}$. In other prisons, however, the katorzhnye could find themselves in a completely different situation. For instance, a report about the katorzhnye in one of the Western regions of the empire ${ }^{86}$ states that despite their sentences that implied hard labour and exile, they were still detained in the local prisons that were not sufficiently guarded. Therefore, other inmates in these prisons had to perform the extramural works despite the fact that they were sentenced to

\footnotetext{
${ }^{82}$ On Sakhalin katorga, see for example GENTES, Andrew. Katorga: Penal Labor and Tsarist Siberia. In: STOLBERG, Eva-M aria (org.) The Siberian Saga: A History of Russia's Wild East. Frankfurt am Main: Peter Lang, 2005, p. 73-85, and GENTES, Andrew. Sakhalin as Cause Célèbre. The Re-signification of Tsarist Russia's Penal Colony. Acta Slavica Japonica, Tomus 32, p. 55-72.

${ }^{83}$ Otchet po Glavnomu tiuremnomu upravleniiu za 1895 god. Saint- Petersburg: Typography of the SaintPetersburg prison, 1897, p. 91-94.

${ }_{84}$ ISAEV, Maksim. Predstoiashchee preobrazovanie katorgi, Pravo, 1911, № 6, 13 February, p. 323.

${ }^{85}$ GARF f.122 op.8 d.1338. The bricks produced there were later used for the construction of more prison buildings, but they have also been sold to private buyers.

${ }^{86}$ GARF f.122 op.48 d.1171/1910 I.2. This is a report about Chernigov (Northern Ukraine) region.
} 
lighter punishment, while the katorzhnye would spend the whole days without any occupation.

Somewhat similar situation was observable already in the 1860s: until the introduction of obligatory convict labour in 1886 the prisoners who were generally obliged to work were sentenced by the magistrates of peace [mirovoi sudia] rather than the criminal court. These people committed less serious wrongdoings than the criminals, and were sent to the workhouses. However, in the regular prisons prior to 1886 the criminal convicts had the right to choose whether they preferred to work or not, even if the facilities were there ${ }^{87}$.

\section{Conclusion}

The last decades of the nineteenth century were marked by the advance of the prison reform in Russia. Compared to the "Great reforms", this process could look trivial: spanning over the course of almost four decades, it did not involve an immediate improvement of the condition of prisoners, and at least in the beginning was limited to the administrative transformation. As I have shown, the pace and the nebulous shape of this reform was partly defined by the functioning of the nascent Imperial bureaucracy. However, concentrating on 1879 as the single moment of reform does not allow to perceive its scope. The significance of the reform can only be seen in the long run: the reform initiated the development of a new, knowledge-based and centralized, way of managing the prisons.

The emergence of this new approach gains additional significance when we look beyond the revolutionary divide: the ways in which this reform has re-organized the prison system have largely been re-appropriated by the Bolsheviks. Moreover, as it was suggested by Daniel Beer, "the most basic continuity between Late Imperial Russian liberalism and early Soviet radicalism lay in the assumption that human material could and should be remolded"88. The introduction of obligatory "rehabilitative" labour for the prisoners, centralization of prison administration, elaborating the techniques for

\footnotetext{
87 Obzor, 1889, p. 15.

${ }^{88}$ BEER, Daniel. Blueprints for Change: The Human Sciences and the Coercive Transformation of Deviants in Russia, 1890-1930. Osiris, vol. 22, no. 1, 2007, p. 29.
} 
meticulous registration of the everyday life of inmates were the crucial measures that facilitated such attempts of remolding.

The driver of this change was the Main Prison Administration. Right from its creation it was preoccupied with the development of the new "rational" approaches to the penal system, gradually collecting information about prisons within and without the Russian empire, appropriating and developing different conceptions of punishment, and searching for the optimal settings of confinement and forced labour. This approach was quite limited in practice, and the precise scope of these limitations is hardly observable: historical sources cannot grasp these limitations even approximately, as we only know what the officials knew, but there is no possibility of establishing what escaped them. Despite these limitations it is nevertheless clear that the transformation of the penal system over the course of the twenty six years that I examined here was profound: its management was gradually yet persistently centralized, the new information-based approaches to the organization of punishment and convict labour were gaining ground, and all kinds of new techniques of documenting the life of convicts - from photographing the inmates to using new uniform blanks for the personal dossiers - were used in more and more regional prisons.

Although this is not a statement that can be explicitly supported by the sources, it's possible to suggest that the obligatory convict labour was particularly compelling for the administrators of the GTU due to the development of industry in the second half of the nineteenth century. However, the feeble industrialization of the country in general also made it hard to develop the forced labour of prisoners as the officials have conceived it, namely based on workshops where the prisoners would learn new skills and produce marketable goods. The attempts to introduce the schemes of imprisonment developed in the most industrialized regions of Western Europe were confronted with the realities of an overwhelmingly agrarian country with a generally low density of population.

Data de recebimento do artigo: 15/10/2016

Data de aprovação do artigo: 02/11/2016 


\section{Bibliography}

ADAMS, Bruce F. The Politics of Punishment: Prison Reform in Russia, 1863-1917. Northern Illinois University Press: DeKalb, 1996.

BADCOCK, Sarah. From villains to victims: experiencing illness in Siberian exile. Europe-Asia Studies, 2013, n. 65(9). p.1716-1736.

BEER, Daniel. Blueprints for Change: The Human Sciences and the Coercive Transformation of Deviants in Russia, 1890-1930. Osiris, vol. 22, no. 1, 2007.

BEER, Daniel. Renovating Russia: the Human Sciences and the Fate of Liberal M odernity, 1880-1930. Ithaca: Cornell University Press, 2008.

CORRADO, Sharyl M. The "End of the Earth": Sakhalin Island in the Russian Imperial Imagination, 1849-1906. PhD. dissertation, University of Illinois at UrbanaChampaign, 2010.

DIKÖTTER Frank. The Promise of Repentance: Prison Reform in Modern China. The British Journal of Criminology, vol. 42. no.2, spring 2002. pp. 240-249.

EKLOF, Ben; BUSHNELL John; ZAKHAROVA Larisa Georgievna (org.). Russia's Great Reforms, 1855-1881. Indiana University Press, 1994.

FOUCAULT, M ichel. Surveiller et punir. Paris: Gallimard, 1975.

GENTES, Andrew. Katorga: Penal Labor and Tsarist Siberia. In: STOLBERG, Eva-Maria (org.) The Siberian Saga: A History of Russia's Wild East. Frankfurt am Main: Peter Lang, 2005. pp.73-85.

GENTES, Andrew. Sakhalin as Cause Célèbre. The Re-signification of Tsarist Russia's Penal Colony. Acta Slavica Japonica, Tomus 32, pp.55-72.

HOLQUIST, Peter. "In Accord with State Interests and the People's Wishes": The Technocratic Ideology of Imperial Russia's Resettlement Administration. Slavic Review 69, no. 1. spring 2010. pp.151-179.

IGNATIEFF, Michael. A Just Measure of Pain: Penitentiaries in the Industrial Revolution, 1780-1850. London: Macmillan, 1978.

ISAEV, Maksim. Osnovy penitentsiarnoi politiki. Moscow: Gosizdat, 1926.

KENNAN, George. Siberia and the Exile System vol. 2. New York: Century CO, 1891.

LIEVEN, Dominic (org.) Cambridge History of Russia, vol.2. Cambridge: Cambridge University Press, 2006. 
LIEVEN, Dominic. Russia's Rulers Under the Old Regime. New Haven and London: Yale University Press, 1990.

M AKSIM OV, Serguei. Sibir i katorga. Saint- Petersburg, 1900.

MARGOLIS, Aleksandr. Tiurma i ssylka v imperatorskoi Rossii. Moscow: Laterna Vita, 1995.

RAEFF, Marc. The Russian Autocracy and Its Officials. In MCLEAN, Hugh et al. (org.). Russian Thought and Politics. Cambridge: Harvard University Press, 1957.

RIEBER, Alfred. Bureaucratic Politics in Imperial Russia. Social Science History 2, no. 4. p. 399-413. Summer 1978.

ROBBINS, Richard G., Jr. The Tsar's Viceroys. Ithaca and London: Cornell University Press, 1987.

SCHRADER, Abby M. Languages of the Lash: Corporal Punishment and Identity in Imperial Russia. Northern Illinois University Press, 2002.

SCHRADER, Abby M. The Languages of the Lash: the Russian Autocracy and the Reform of Corporal Punishment, 1817-1893. PhD. dissertation. University of Pennsylvania, 1996.

SPIERENBURG, Pieter. The Prison Experience: Disciplinary Institutions and their Inmates in Early Modern Europe. New Brunswick, London: Rutgers University Press, 1991.

ZUBOV, Serguei. M.N. Galkin-Vraskoi - nachalnik Glavnogo Tiuremnogo upravleniia Rossiiskoi Imperii (1879-1896 gg.). Saratov, 2007. 